\title{
Sugarcane productivity simulation under different planting times by DSSAT/CANEGRO model in Alagoas, Brazil
}

\author{
André Luiz de Carvalho1*, José Leonaldo de Souza', Alexsandro Claúdio Dos Santos Almeida', \\ Gustavo Bastos Lyra², Guilherme Bastos Lyra', ledo Teodoro', Ricardo Araújo Ferreira Junior', \\ Ivomberg Dourado Magalhães ${ }^{1}$, Lekson Rodrigues Santos ${ }^{1}$
}

${ }^{1}$ Federal University of Alagoas (UFAL), Av. Lourival Melo Mota, s/n - Tabuleiro dos Martins, Maceió - AL - Brasil - CEP: 57072-900,

${ }^{2}$ Federal Rural University of Rio de Janeiro (UFRRJ), BR-465, Km 7, Seropédica - RJ - Brasil - CEP: 23897-000

\section{A B S TR A C T}

In sugarcane crop, it is important to search for tools to assist in the agricultural management to increase the yield and minimize the costs of production. Dynamics growth models are tools that help management, supporting the analysis of making complex decisions, allowing reducing cost, time and human resources. Thus, the aim of this study was to determine the best time of planting for the sugarcane crop using the DSSAT/CANEGRO model for the region of Rio Largo, state of Alagoas, Northeastern Brazil. The crop, soil and meteorological data used in the simulations were obtained in field experiment carried out at sugarcane cropping in years 2003 and 2006 . The sugarcane varieties used in the experiment was RB93509 in two crop cycles (plant crop and ratoon crop). Planting was held on October 1, 2003 and the $1^{\text {st }}$ harvest (plant crop) took place on October 1, 2004 and the $2^{\text {nd }}$ harvest (ratoon crop) took place on February 25, 2006. The model performance was quantified by different statistical tests (Error Model, Medium Error Quadratic Root and Determination Coefficient). The model satisfactorily simulated the fresh $(0.6$ and $11.0 \%)$ and dry matter production $(-19.2$ and $18.1 \%)$, tillering $\left(R^{2}=0.69\right.$ and 0.80$)$, plant height $(0.0$ and $-19.1 \%)$ and leaf area index $\left(R^{2}=0.87\right.$ and 0.73$)$. The best planting time for sugarcane crop was on October 30 . However, in El Niño and La Niña years of strong intensity, the best planting time was on January 15 and September 30 , respectively.

Keywords: Agricultural Modelling; Saccharum officinarum L.; Sowing times

\section{INTRODUCTION}

The state of Alagoas stands out as the largest sugarcane producer in Northeastern Brazil and the fifth largest in the country. The state lost the second position that it has been held for years, since its production has stagnated in the past two decades, while the country has doubled its area. In addition, the average yield is much lower $(53.9 \mathrm{t}$ $\left.\mathrm{ha}^{-1}\right)$ compared to the other states, such as São Paulo and Minas Gerais, where yield is above $70 \mathrm{t} \mathrm{ha}^{-1}$ (Abreu et al., 2013). It is essential to improve the level of technology used in sugarcane cultivation in the state to increase the yield of sugarcane fields.

To obtain high yield, it is necessary to cultivate varieties with high yield potential and adapted to local conditions. In the state of Alagoas, there is good availability and use of productive varieties, as it hosts important genetic improvement programs for sugarcane. However, there is a significant difference between yields obtained and productive potential, showing that it is necessary to properly plan agricultural activities to reduce this difference. Dynamic crop growth models are tools used to assist in this planning. They allow greater understanding of the crop and its behavior in different management scenarios and climate, assisting in decision making (Thorp et al., 2008; Marin and Jones, 2014; Carvalho et al., 2015).

The DSSAT model (Decision Support System for Agrotechnology Transfer) has been used to simulate sugarcane growth: Dry biomass partitioning (Singels and Bezuidenhout, 2002); tiller density and light interception (Bezuidenhout et al., 2003); water extraction, growth and sucrose accumulation in water stress conditions (Singels

\footnotetext{
*Corresponding author:

André Luiz de Carvalho, Federal University of Alagoas (UFAL), Av. Lourival Melo Mota, s/n - Tabuleiro dos Martins,

Maceió - AL - Brasil - CEP: 57072-900. E-mail: del.andre2@hotmail.com
}

Received: 31 July 2017; $\quad$ Accepted: 18 February 2018 
et al., 2010) and forecasts for future scenarios with climate change (Knox et al., 2010; Silva, 2012; Marin et al., 2012; Jones et al., 2015). In Brazil, DSSAT is used to simulate the growth and production variables of different sugarcane varieties in São Paulo (Nassif et al., 2012), analyze the impact of climate change on sugarcane productivity in Bahia (Silva, 2012) and São Paulo (Jones et al., 2015).

However, in order to obtain good yields and great longevity of sugarcane plantations, the planting time and agricultural practices during sugarcane plantations should be rigorously planned and performed in order to guarantee good and rapid crop establishment in the field (Fietz et al., 2015). Thus, the use of these agricultural models is of great importance for the planning and performance of these activities.

The results of the above studies report that the DSSAT model is a promising tool for the simulation of sugarcane growth and yield. Thus, the aim of this study was to determine the best time of planting for the sugarcane crop using the DSSAT/CANEGRO model for the region of Rio Largo, state of Alagoas, Brazil.

\section{MATERIAL AND METHODS}

\section{Experimental data}

Data measured in the field were obtained by Almeida et al. (2008) in an experiment carried out in the experimental area of Agrometeorology, Center for Agricultural Sciences (CECA) of the Federal University of Alagoas (UFAL), Rio Largo, Alagoas, Northeastern Brazil. The region of

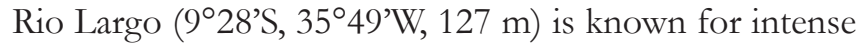
sugarcane cultivation due to the presence of semi-humid and hot climate with rainy season between March and August and dry season from September to February. The average annual rainfall is $1,800 \mathrm{~mm}$, the average annual temperature is $25.4^{\circ} \mathrm{C}$ and average relative humidity above 70\% (Souza et al., 2004; Ferreira Junior et al., 2014).

The soil of the experimental area is classified as Cohesive Argisolic Yellow Latosol medium-clay texture according to analysis of the Department of Soil Physics at CECA/ UFAL, with mild topography and slope less than $2 \%$. The experimental design was a randomized blocks design with five replicates and four treatments. The experiment was conducted in an area of $500 \mathrm{~m}^{2}$ subdivided into plots of five cultivation lines with 4 linear meters. The sugarcane variety evaluated was RB93509 in two crop cycles (plant crop and ratoon crop). Planting was held on October 1, 2003 and the $1^{\text {st }}$ harvest (plant crop) took place on October 1, 2004 and the $2^{\text {nd }}$ harvest (ratoon crop) took place on February 25, 2006. In plant crop was applied a foundation fertilization with $70 \mathrm{~kg}$ of $\mathrm{N} \mathrm{ha}^{-1}, 60 \mathrm{~kg}$ of $\mathrm{P}_{2} \mathrm{O}_{2} \mathrm{ha}^{-1}$ e $120 \mathrm{~kg}$ of $\mathrm{K}_{2} \mathrm{O}$ $\mathrm{ha}^{-1}$. A fertilization applied to the ratoon crop was in the same quantity of plant crop. Liming and fertilization were applied according to the chemical analysis of soil. Irrigations performed on the stages of establishment in both cycles were based on crop evapotranspiration (ET $\mathrm{E}_{c}$, calculated by multiplying the reference evapotranspiration (ET) by single $\mathrm{K}_{\mathrm{c}}$ of FAO-56 (Allen et al., 1998). Detailing the cultivation and growth analyses are presented in Almeida et al. (2008). The meteorological elements (global solar radiation, maximum and minimum air temperature, rainfall, wind speed and air humidity) were measured in an automatic agrometeorological station (Micrologger CR10X, Campbell Sci., Logan, Utah).

\section{DSSAT model}

For the simulation of sugarcane growth and development variables, the CANEGRO model was used, which is included in the DSSAT model (Jones et al., 2003; Singels et al., 2008). The DSSAT model is free software used by students from around of the world in research aimed at simulating the productivity of several agricultural crops. The parameterization of the DSSAT/CANEGRO model consisted of inserting climate data [global solar radiation $\left(\mathrm{W} \mathrm{m} \mathrm{m}^{-2}\right.$, maximum and minimum air temperature $\left({ }^{\circ} \mathrm{C}\right)$, rainfall $(\mathrm{mm})$, wind speed $\left(\mathrm{m} \mathrm{s}^{-1}\right)$ and air humidity $\left.(\%)\right]$ and soil data [classification, texture (sand, silt and clay content), density and $\mathrm{pH}$ ] of the study area. In addition, the model also requires data that regulate the hydrophysical soil properties such as field capacity, permanent wilting point, water saturation and soil depth, based on processes of sugarcane growth and development modeling, including phenology, canopy growth, biomass and sucrose accumulation, partitioning, root growth, water stress and lodging (Nassif et al., 2012; Ritchie, 1998; Singels et al., 2008). Crop management data (variety, spacing between rows, plant population, and information regarding the amount and date on irrigation and fertilization application) are also required.

The model was fitted through changes made on specific parameters related to sugarcane crop (Table 1), from a variety (NCo376) previously calibrated in the DSSAT/ CANEGRO model as suggested by Singels et al. (2008).

\section{Planting times simulated by the DSSAT model}

Fresh and dry matter yield at different planting times was analyzed using the DSSAT model. The selected dates were: Aug 15, Aug 30, Sep 15, Sep 30, Oct 15, Oct 30, Nov 15, Nov 30, Dec 15, Dec 30, Jan 15, Jan 30, Feb 15, Feb 28, Mar 15, Mar 30 and Apr 15. The harvesting period occurred after 12 months of each planting time. Later, the impact of El Niño-Southern Oscillation events (El Niño and La Niña) on the planting time was analyzed. ENSO events 
Table 1: Input parameters of the DSSAT/CANEGRO model for sugarcane

\begin{tabular}{|c|c|c|c|c|}
\hline Parameter & Unit & Description & NCo376 & RB93509 \\
\hline Parcemáx & $\mathrm{g} \mathrm{MJ}^{-1}$ & $\begin{array}{l}\text { Maximum (no stress) radiation conversion efficiency expressed } \\
\text { as assimilate produced before respiration, per unit of PAR. }\end{array}$ & 9.9 & 9.9 \\
\hline APFMX & $\mathrm{Mg} \mathrm{Mg}^{-1}$ & $\begin{array}{l}\text { Maximum fraction of dry mass increments that can be allocated } \\
\text { to aerial dry mass. }\end{array}$ & 0.88 & 0.88 \\
\hline STKPFmáx & $\mathrm{Mg} \mathrm{Mg}^{-1}$ & $\begin{array}{l}\text { Fraction of daily aerial dry mass increments partitioned to stalk } \\
\text { at high temperatures in a mature crop. }\end{array}$ & 0.65 & 0.75 \\
\hline Suca & $\mathrm{Mg} \mathrm{Mg}^{-1}$ & Maximum sucrose contents in the base of stalk. & 0.58 & 0.58 \\
\hline TBFT & $\stackrel{\circ}{ }$ & $\begin{array}{l}\text { Temperature at which partitioning of unstressed stalk mass } \\
\text { increments to sucrose is } 50 \% \text { of the maximum value. }\end{array}$ & 25 & 25 \\
\hline Tthalfo & ${ }^{\circ} \mathrm{C} d$ & Thermal time to half canopy. & 250 & 250 \\
\hline Tbase & $\stackrel{\circ}{\mathrm{C}}$ & Base temperature for canopy development. & 16 & 16 \\
\hline LFmáx & Leaves & $\begin{array}{l}\text { Maximum number of green leaves a healthy, } \\
\text { adequately-watered plant will have after it is old enough to lose } \\
\text { some leaves. }\end{array}$ & 12 & 12 \\
\hline MXLFArea & $\mathrm{cm}^{2}$ & $\begin{array}{l}\text { Maximum leaf area assigned to all leaves above leaf number } \\
\text { MXLFArno. }\end{array}$ & 360 & 500 \\
\hline MXLFArno & Leaf & Leaf number above which leaf area is limited to MXLFArea. & 15 & 18 \\
\hline Pl1 & ${ }^{\circ} \mathrm{C} d$ & Phyllocron interval 1 for leaf numbers below Pswitch. & 69 & 69 \\
\hline $\mathrm{Pl} 2$ & ${ }^{\circ} \mathrm{C} \mathrm{d}$ & Phyllocron interval 2 for leaf numbers above Pswitch. & 169 & 250 \\
\hline Pswitch & Leaf & Leaf number at which the phyllocron changes. & 18 & 18 \\
\hline TTPLNTEM & ${ }^{\circ} \mathrm{C} d$ & Thermal time to emergence for a plant crop. & 428 & 830 \\
\hline TTRATNEM & ${ }^{\circ} \mathrm{C} d$ & Thermal time to emergence for a ratoon crop. & 203 & 400 \\
\hline ChupiBase & ${ }^{\circ} \mathrm{C} d$ & Thermal time from emergence to start of stalk growth. & 1.050 & 1.050 \\
\hline TT_PopGrowth & ${ }^{\circ} \mathrm{C} d$ & Thermal time to peak tiller population. & 600 & 300 \\
\hline Max_Pop & Stalks $\mathrm{m}^{-2}$ & Maximum tiller population. & 30 & 20 \\
\hline PopTT16 & Stalks $\mathrm{m}^{-2}$ & Stalk population at/after $1600^{\circ} \mathrm{C} \mathrm{d}^{-1}$ & 13.3 & 8.3 \\
\hline LG_AMBase & $\mathrm{Mg} \mathrm{ha}^{-1}$ & $\begin{array}{l}\text { Aerial mass (fresh mass of stalks, leaves, and moisture) at } \\
\text { which lodging start. }\end{array}$ & 220 & 220 \\
\hline
\end{tabular}

with different intensities were used: Weak, moderate and strong. ENSO event classification was obtained at http:// ggweather.com/enso/oni.htm.

\section{Statistical analysis}

The model performance for simulations of the growth variables of sugarcane varieties (fresh matter and dry matter production, number of tillers, Leaf Area Index and plant height) was quantified by different statistical tests, such as: Model Error $( \pm 20 \%)$, Root Mean Square Error (RMSE) and determination coefficient $\left(\mathrm{R}^{2}\right)$. To determine the best planting time, the method of percentiles was used, in which 1, 20, 50, 80 and 99 percentiles were calculated.

\section{RESULTS AND DISCUSSION}

\section{Evaluation of the DSSAT/CANEGRO model Growth variables analyses}

The fresh and dry matter production (Fig. 1) simulated by the model were close to values obtained in the field experiment. In the plant crop cultivation, fresh matter simulated was $110.9 \mathrm{t} \mathrm{ha}^{-1}$, which was only $0.6 \%$ above the obtained in the field $\left(110.3 \mathrm{t} \mathrm{ha}^{-1}\right)$. Abreu et al. (2013) analyzed the productivity of six varieties for three cycles, and this variety stood out in plant crop cultivation. In many variety competition experiments conducted in Northeastern Brazil, this variety has stood out (Abreu et al., 2013; Almeida et al., 2008; Teodoro et al., 2015). For ratoon crop cultivation, the model overestimated by $11 \%$. This estimate error value is less than $\pm 20 \%$ within an error range considered acceptable. Nassif et al. (2012) found similar results for variety RB67515, in which the same model overestimated the fresh matter accumulation throughout the plant crop cycle.

For the dry matter, the model also underestimated the plant crop cultivation and overestimated the ratoon crop, but showed higher estimation errors. The value found for plant crop was $37.8 \mathrm{t} \mathrm{ha}^{-1}$, value close to those simulated by the model, which was $30.5(-19.2 \%)$ tha $^{-1}$. Silva (2012) observed dry matter content of $50 \mathrm{t} \mathrm{ha}^{-1}$ in variety RB92579. In ratoon crop, the simulated value was $35.6(18.1 \%) \mathrm{t} \mathrm{ha}^{-1}$. It was observed that the dry matter productivity simulated by the model also showed higher errors for ratoon crop, although most of the results are within the acceptable error ( $\pm 20 \%$ ). Singels et al. (2008), Marin et al. (2011), Marin and Jones (2014) reported high variations in the estimate of this parameter in the modeling. Although satisfactory, results show a slight deficiency in the fresh and dry matter yield simulation model in ratoon crop and that can still be adjusted. 
Increased tillering was sharp early in the cycle, peaking at 120 DAP in the first cycle (plant crop) and 60 CAD in the second cycle (ratoon crop) (Fig. 2). After the occurrence of the peak tillering, there was a sharp decline, with $50 \%$ natural reduction in plant population (Almeida et al., 2008). This variety differs considerably in tiller number, and in general and the value produced was 8.3 and 10.5 plants $\mathrm{m}^{-2}$ in plant and ratoon crops, respectively, whose values are similar to other Brazilian varieties simulated in the same model (Nassif et al., 2012). These results showed good correlation with validated values and generated $\mathrm{R}^{2}$ values of 0.69 and 0.80 for plant crop and ratoon crop, respectively. The RMSE values were low, confirming the good correlation. The model could not predict the tillering trend curve in ratoon crop, even if the final value has been the same of the standard range (NCo376) (Table 1). This difficulty may be due to the tillering standard of the variety in the first ratoon procedure, which does not follow the quadratic representation of trend curves as a function of time. In evaluating the relationship between the number of tillers as a function of time in three cycles (plant, ratoon and r-ratoon) of six varieties in the same region, variety
RB92579 in ratoon crop was the only one who did not follow this trend (Abreu et al., 2013).

In simulation in plant crop, the model tended to anticipate the peak tillering in approximately 30 days $(90$ simulated DAP, 120 observed DAP). Nassif et al. (2012), and Marin et al. (2011) observed the same precocity trend for other Brazilian varieties, which can be related to their growth patterns that show rapid growth in the early stages and increased leaf area causing increased light interception by higher plants and shading of lower plants (Marin and Jones, 2014). This shows that the tillering rate is highly correlated with the light interception by the canopy (Bezuidenhout et al., 2003). However, the model calculates this rate only as a function of air temperature (Marin and Jones, 2014).

For ratoon crop, simulating the peak coincided with values observed in field. Comparing the simulated tillering data to those observed, the results of the statistical tests in plant crop were: $\mathrm{R}^{2}=0.69$ (plant crop) and $\mathrm{R}^{2}=0.80$ (ratoon crop), and RMSE $=3.2$ (plant crop) and RMSE $=2.0$ (ratoon crop). However, the model satisfactorily represented the

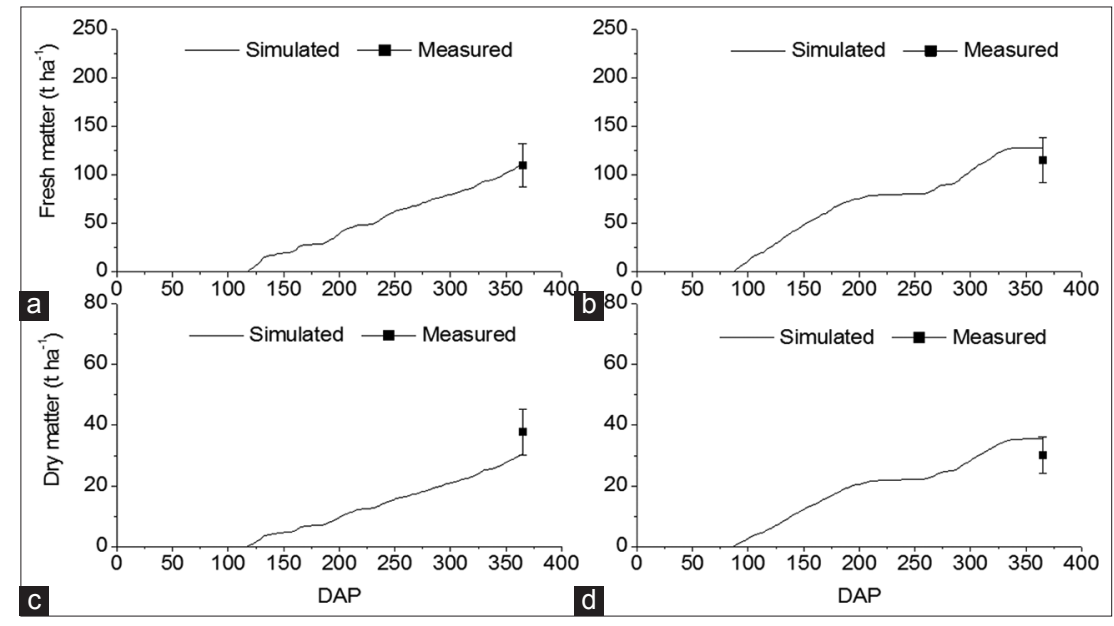

Fig 1. Fresh and dry matter production $\left(\mathrm{Mg} \mathrm{ha}^{-1}\right)$ measured and simulated by the DSSAT/CANEGRO model in plant crop (a, $\mathrm{c}$ ) and ratoon crop (b, d) for Rio Largo, Alagoas.

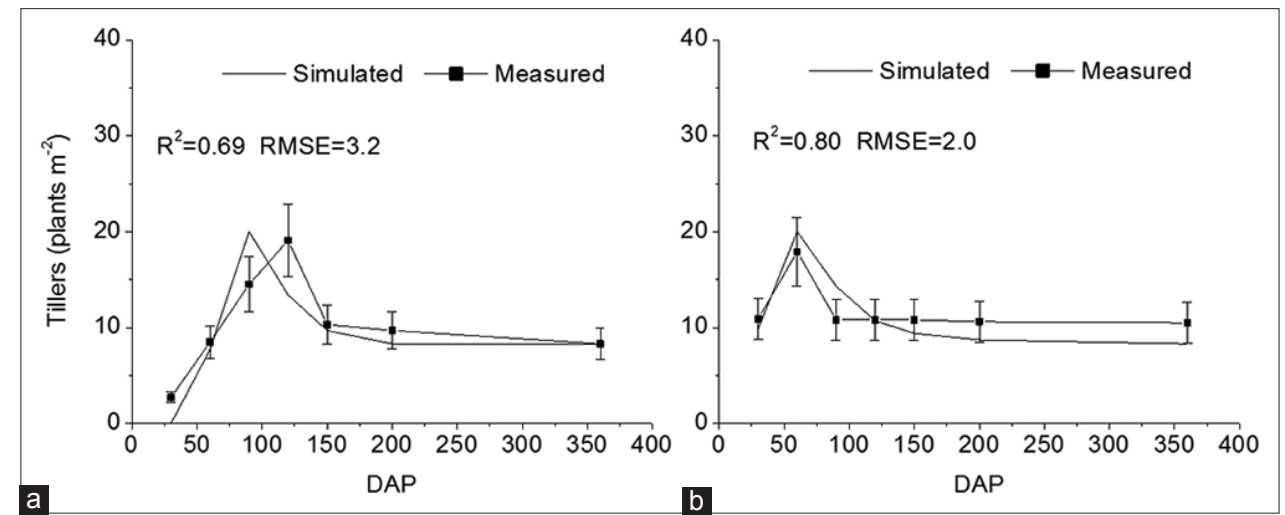

Fig 2. Number of tillers (plants $\mathrm{m}^{-2}$ ) measured and simulated by DSSAT/CANEGRO model in plant crop (a) and ratoon crop (b) for Rio Largo, Alagoas. 
sharp decline in the number of plants after plants reached that peak. The maximum tillering value measured was 19.1 plants $\mathrm{m}^{2}$ (plant crop) and $17.9 \mathrm{~m}^{-2}$ plants (ratoon crop). The maximum tillering value simulated by the model was close to measured values, with 27.6 to 20 plants $\mathrm{m}^{-2}$ (plant crop) and 27.1 to 20 plants $\mathrm{m}^{-2}$ (ratoon crop), with errors, in most simulations, less than $12 \%$. This tillering pattern is similar to that described by Bezuidenhout et al. (2003) and by Marin and Jones (2014), as well as the standard variety (NCo376) of the model (Singels et al., 2008). This contributed to a better fit for this parameter in this variety.

The model satisfactorily simulated the Leaf Area Index (LAI) values and also the trend of growth curves in both crop cycles (Fig. 3). Comparing the simulated LAI data to those observed, the results of statistical tests were $\mathrm{R}^{2}=0.87$ (plant crop) and $\mathrm{R}^{2}=0.73$ (ratoon crop), and RMSE $=0.5$ (plant crop) RMSE $=0.9$ (ratoon crop). These results can be considered acceptable when compared with results from other research that studied LAI simulations, RMSE of 0.82 (Silva, 2012), $\mathrm{R}^{2}$ from 0.92 to 0.98 and RMSE from 0.42 to 0.73 (Nassif et al., 2012), RMSE of 0.89 (Marin and Jones, 2014), $R^{2}$ of 0.78 and RMSE of 1.0 (Marin et al., 2011).

The results showed continued growth, increasing in plant crop by the end of the cycle, reaching maximum value of $3.7 \mathrm{~m}^{2} \mathrm{~m}^{-2}$, but in ratoon crop, LAI was reduced from the maximum value, which was $4.9 \mathrm{~m}^{2} \mathrm{~m}^{-2}$ at 210 DAP (Fig. 3). The maximum LAI values simulated by the model were $3.4 \mathrm{~m}^{2} \mathrm{~m}^{-2}(-8 \%)$ in 330 DAP in plant crop and $3.8 \mathrm{~m}^{2} \mathrm{~m}^{-2}$ $(-23 \%)$ in 180 DAP in ratoon crop.

In the simulated LAI curves, a decline between periods from 130 to 180 DAP was observed, and then returning to growth. This was due to the model's response to the occurrence of water deficits during this period. However, under field conditions, this decline was not observed, but rather a reduction in the growth rate of LAI, but it continued to grow, only more slowly than in the period before and after the water stress (Almeida et al., 2008). Sugarcane crop has several mechanisms to reduce the effects of water stress on crop growth, highlighting the variety that is the most widespread in Northeastern Brazil, where environmental conditions vary widely. These mechanisms hinder the modeling, while Bezuidenhout et al. (2003) and Van Antwerpen (1998) consider that DSSAT simulates very severely the effects of water stress on sugarcane crop. This indicates that this model has some limitations for crop simulations under rainfed conditions and therefore, further studies on the effect of drought on the development of LAI and canopy should be conducted (Marin and Jones, 2014).

Plant height simulated by the model showed good performance, although in ratoon crop, the model showed higher errors (Table 2). Plant height was simulated at $2.3 \mathrm{~cm}$ $(1.0 \%)$ in plant crop and $2.1 \mathrm{~cm}(-19.1 \%)$ in ratoon crop.

\section{Water balance analyses}

DSSAT model simulated accumulated transpiration and evaporation with good performance, for both plant crop and ratoon crop. Initially, evaporation was higher than transpiration due to slow sugarcane growth, but in all cases total accumulated transpiration was higher (Fig. 4). The model obtained good performance in crop evapotraspiration (ETc) simulations, but these simulations were overestimated. ETc was simulated at $1330 \mathrm{~mm}$ $(23.8 \%)$ in plant crop and $1159 \mathrm{~mm}(18.2 \%)$ in ratoon crop.

According to Allen et al. (1998) in field conditions, the relationship between the evaporation of the bare soil and ETo generally ranges from 25 to $40 \%$. In this study it was not possible to estimate it, but we calculated the relationship between evaporation (E) and transpiration $(\mathrm{T})$ with real (ETr) and crop evapotranspiration (ETc). The E/ETr was $44 \%$ in plant crop and $32 \%$ in ratoon crop, and $\mathrm{T} / \mathrm{ETr}$ was $56 \%$ in plant crop and $68 \%$ in ratoon crop. The E/ETc

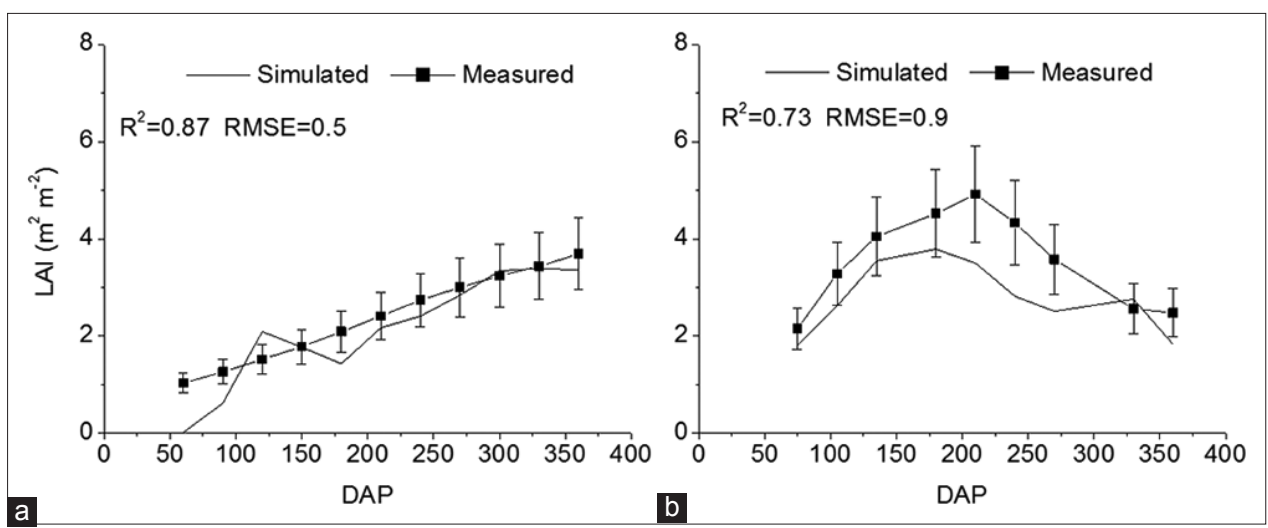

Fig 3. Leaf Area Index $\left(\mathrm{m}^{2} \mathrm{~m}^{-2}\right)$ measured and simulated by the DSSAT/CANEGRO model in plant crop (a) and ratoon crop (b) for Rio Largo, Alagoas. 
was $32 \%$ in plant crop and $20 \%$ in ratoon crop, and T/ETc was $42 \%$ in plant crop and $42 \%$ in ratoon crop.

\section{$L A / x$ water stress}

Analyzing LAI behavior in relation to water stress for growth it was observed that these components are inversely proportional (Fig. 5). In plant crop, the period with less rainy days occurrences (until $230 \mathrm{DAP}$ ) the crops suffered influence of water stress, which had direct impact over their growth and consequently reducing LAI values. Irrigation use was just done to minimize the effect of water stress in these drier periods. In the beginning of the development of LAI, it was observed that water stress was not intense (around 100 DAP) and then a slight increase occurred, but as water stress became more intense LAI values were reduced. After that (230 to 330 DAP), crops did not suffered with water stress because rain occurrences, so that

Table 2: Plant height $(\mathrm{cm})$ measured and simulated by the DSSAT/CANEGRO model in plant crop and ratoon crop for RB93509 variety

\begin{tabular}{lcc}
\hline Plant height $(\mathbf{c m})$ & Plant crop & Ratoon crop \\
\hline Measured & 2.3 & 2.6 \\
Simulated & 2.3 & 2.1 \\
Error (\%) & 0 & -19.1 \\
\hline
\end{tabular}

LAI values became to increase again (final value greater than $3 \mathrm{~m}^{2} \mathrm{~m}^{-2}$. In ratoon crop, LAI values were favored in the beginning of the cycle because greater demand of water (until $170 \mathrm{DAP}$ ). After that, the crops suffered an intense water stress (200 a 280 DAP) reducing LAI values (final value greater than $1.5 \mathrm{~m}^{2} \mathrm{~m}^{-2}$ ). According to Boutraa et al. (2010) water stress lead to growth reduction, which was reflected in plant height, dry weight, leaf area and other growth functions.

\section{Evaluation of different planting times for sugarcane}

After calibration, the DSSAT model was used in several simulations to obtain the best planting times of sugarcane for the region of Rio Largo. Large fluctuations were observed among fresh and dry matter values simulated at the different planting times considered (Fig. 6). The results in Table 3 show that the best times to plant sugarcane occurred on October 30 and November $30\left(99^{\text {th }}\right.$ and $80^{\text {th }}$ percentiles respectively), obtaining fresh matter values of 101.9 and $99.9 \mathrm{t} \mathrm{ha}^{-1}$ and dry matter values of 28.2 and $27.6 \mathrm{t} \mathrm{ha}^{-1}$. Table 3 also showed that April 15 is not recommended for planting sugarcane (percentile 1), which obtained fresh matter value of $59.9 \mathrm{t} \mathrm{ha}^{-1}$ and dry matter value of $15.8 \mathrm{t} \mathrm{ha}^{-1}$. In addition, it could be concluded that

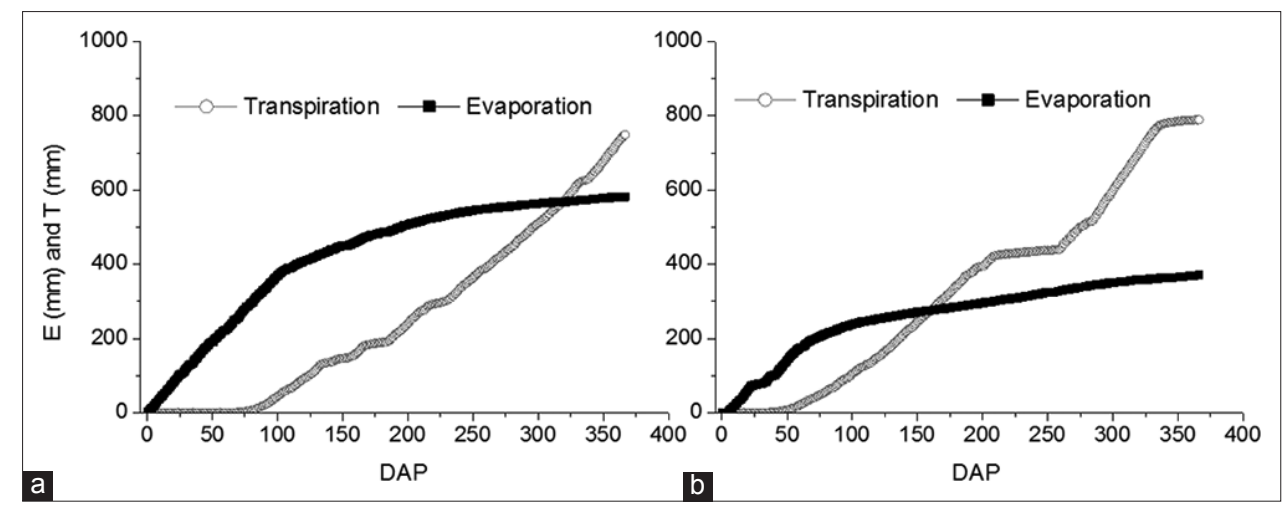

Fig 4. Accumulated transpiration $(\mathrm{T} ; \mathrm{mm})$ and evaporation $(\mathrm{E} ; \mathrm{mm})$ simulated by the DSSAT/CANEGRO model in plant crop (a) and ratoon crop (b) for Rio Largo, Alagoas.

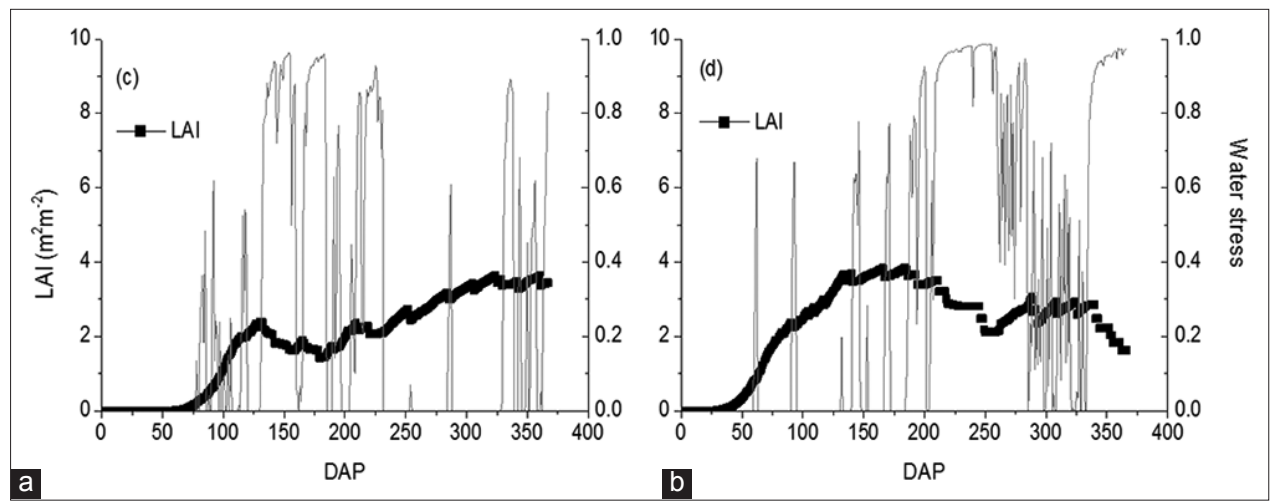

Fig 5. Leaf Area Index $\left(\mathrm{m}^{2} \mathrm{~m}^{-2}\right)$ measured and water stress for growth simulated by the DSSAT/CANEGRO model in plant crop (a) and ratoon crop (b) for Rio Largo, Alagoas. 
if sugarcane is planted after January 15 , productivity would be from 8 to $42.5 \%$ lower than the best-yielding season (October 30). According to Meneses and Resende (2016) in a study carried out in Coruripe-AL, planting sugarcane in November resulted in the lowest soil water deficit and highest effective rainfall value, making it the planting month with less need for irrigation. On the other hand, planting sugarcane in February resulted in higher water surplus, presenting greater need for irrigation.

Fig. 7 shows sugarcane yield results sequentially obtained. It was observed that from August 15, there was a significant increase of fresh and dry matter until reaching the maximum value, previously mentioned, on October 30. From this, there is a constant decreasing evolution until the $15^{\text {th }}$ of April (final date considered in simulations), where the minimum value was observed. According to Meneses and Resende (2016), sugarcane plantations in Coruripe-AL performed on October, November and January maximized stalk and sugar yields, while plantations on February minimized them. It was also observed that productivity difference between the most recommended times (October to December) is lower than that observed between less recommended times (January to April). This

Table 3: Percentiles of different planting times simulated by the DSSAT/CANEGRO model for the 1973-2015 period, EI Niño years and La Niña years for the region of Rio Largo, Alagoas

\begin{tabular}{|c|c|c|c|c|c|c|c|c|c|}
\hline & \multicolumn{3}{|c|}{${ }^{*} 1973-2015$ years } & \multicolumn{3}{|c|}{${ }^{*} E I$ Niño years } & \multicolumn{3}{|c|}{ *La Niña years } \\
\hline & $\begin{array}{c}\text { Fresh Matter } \\
\quad\left(\mathrm{t} \mathrm{ha}^{-1}\right)\end{array}$ & $\begin{array}{c}\text { Dry Matter } \\
\left(\mathrm{t} \mathrm{ha}^{-1}\right)\end{array}$ & Date & $\begin{array}{c}\text { Fresh Matter } \\
\quad\left(\mathrm{t} \mathrm{ha}^{-1}\right)\end{array}$ & $\begin{array}{c}\text { Dry Matter } \\
\left(\mathrm{t} \mathrm{ha}^{-1}\right)\end{array}$ & Date & $\begin{array}{c}\text { Fresh Matter } \\
\left(\mathrm{t} \mathrm{ha}^{-1}\right)\end{array}$ & $\begin{array}{c}\text { Dry Matter } \\
\left(\mathrm{t} \mathrm{ha}^{-1}\right)\end{array}$ & Date \\
\hline Perc1 & 59.9 & 15.8 & 15/Apr & 60.7 & 16.0 & 15/Apr & 58.3 & 15.4 & 15/Apr \\
\hline Perc20 & 81.2 & 22.1 & 28/Feb & 81.8 & 22.3 & 28/Feb & 79.4 & 21.6 & 28/Feb \\
\hline Perc50 & 93.8 & 25.9 & 15/Jan & 94.3 & 26.1 & 30/Jan & 92.7 & 25.5 & 30/Dec \\
\hline Perc80 & 99.9 & 27.6 & $30 / \mathrm{Nov}$ & 100.0 & 27.6 & 30/Sep & 98.3 & 27.1 & $30 / \mathrm{Nov}$ \\
\hline Perc99 & 101.9 & 28.2 & 30/Oct & 102.2 & 28.3 & 30/Oct & 100.1 & 27.7 & $30 /$ Oct \\
\hline
\end{tabular}

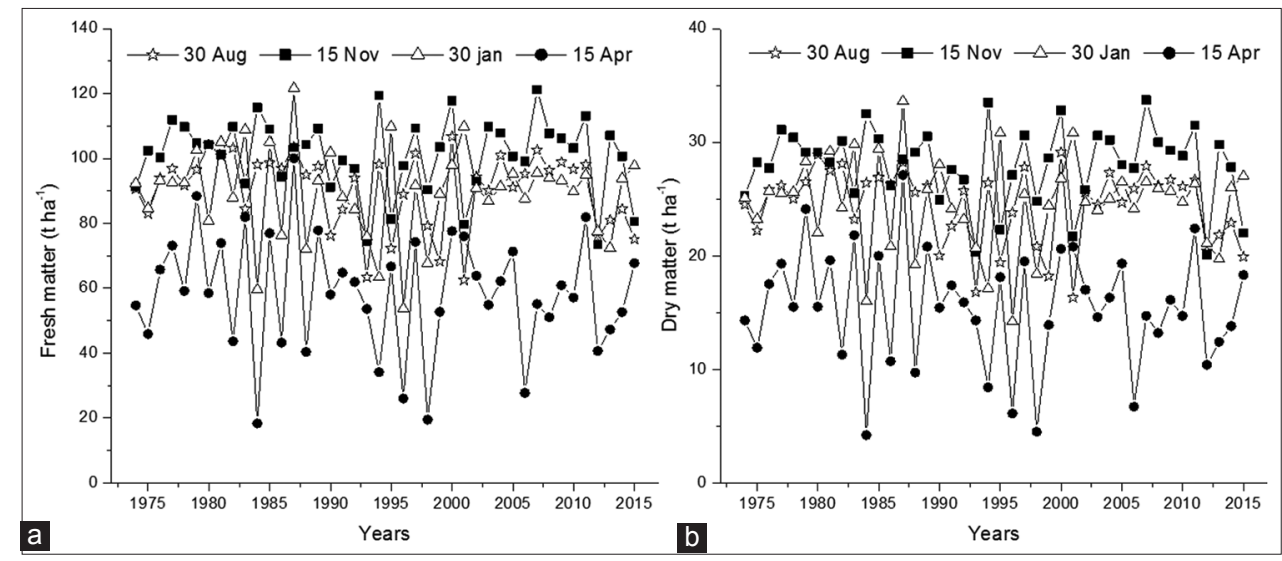

Fig 6. Sugarcane fresh (a) and dry (b) matter simulated by the DSSAT/CANEGRO model under different planting times for Rio Largo, Alagoas.

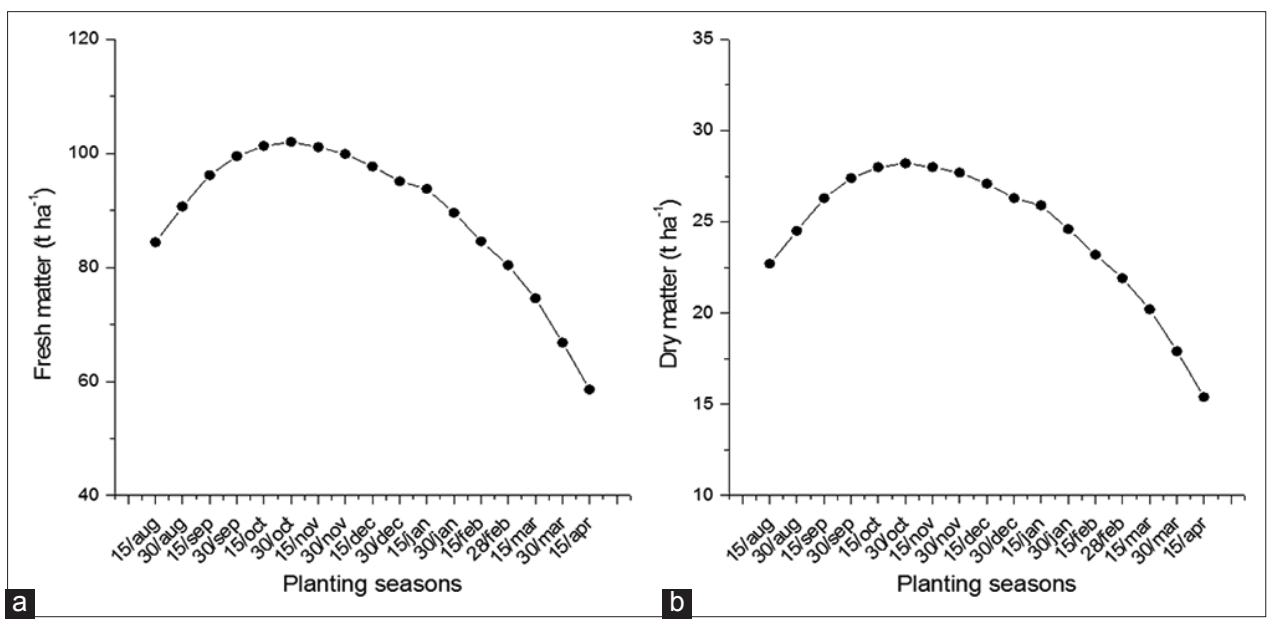

Fig 7. Sugarcane average fresh (a) and dry (b) (1973-2015) matter simulated by the DSSAT/CANEGRO model under different planting times for the region of Rio Largo, Alagoas. 
de Carvalho, et al.

Table 4: Percentiles of different planting times simulated by the DSSAT/CANEGRO model for EI Niño and La Niña with strong intensity for the region of Rio Largo, Alagoas

\begin{tabular}{|c|c|c|c|c|c|c|}
\hline & \multicolumn{3}{|c|}{ EI Niño (1983) } & \multicolumn{3}{|c|}{ La Niña (1974) } \\
\hline & Fresh Matter (t ha-1) & Dry Matter (t ha-1) & Date & Fresh Matter (t ha-1) & Dry Matter (t ha-1) & Date \\
\hline Perc1 & 68.5 & 18.6 & 15/Dec & 55.8 & 14.6 & 15/Apr \\
\hline Perc20 & 82.4 & 21.9 & 15/Apr & 82.5 & 22.5 & 28/Feb \\
\hline Perc50 & 86.9 & 24.0 & 15/Sep & 88.4 & 24.5 & $30 / \mathrm{Nov}$ \\
\hline Perc80 & 92.5 & 25.4 & 28/Feb & 93.7 & 25.8 & 15/Sep \\
\hline Perc99 & 110.6 & 30.4 & 15/Jan & 95.8 & 26.5 & 30/Sep \\
\hline
\end{tabular}

means that a delay or an advance in planting compared to the most recommended times will not have major impacts.

From these results, the real impact of El Niño-Southern Oscillation events (El Niño and La Niña), which is a climatic event that brings serious consequences to rainfall occurrences in different parts of the world was also evaluated. According to Carvalho et al. (2013), the rainy or crop season is modified in relation to its normal occurrence due to the occurrence of an El Niño or La Niña events. According to the author, in El Niño years, the rainy or cultivated season is delayed in its occurrence, also causing a shortening in the total cycle, whereas in La Niña years, anticipation occurs due to the greater occurrence of rain, causing an increase in the total cycle. However, these modifications are more intense when there is an ENSO event with strong intensity. These changes can pose serious risks to the final sugarcane yield if planting is not carried out in an adequate period.

Thus, it was observed that when an event, both El Niño and La Niña occurred, as shown in Table 3, the most recommended time for sugarcane planting did not change (October 30 to the $99^{\text {th }}$ percentile) compared to normal occurrence, presenting small variances in final yield. This means that the occurrence of a simple ENSO event did not characterize major changes in the best planting time of this crop.

However, when observing the occurrence of ENSO events with different intensities (weak, moderate or strong), it was observed that considerable changes in relation to the best planting time may occur (Table 4). In the occurrence of El Niño event of strong intensity such as that occurred in 1983, the most recommended time for planting to the $99^{\text {th }}$ percentile was January 15 (110.6 and $30.4 \mathrm{t} \mathrm{ha}^{-1}$, respectively, for fresh and dry matter). This result was also observed in 1993, which was preceded by an El Niño event of moderate intensity and as a consequence presented low annual precipitation, being considered the driest year of the entire data series, while with the occurrence of a La Niña event of strong intensity, such as that occurred in 1974, the most recommended planting time was September 30 (95.8 and $26.5 \mathrm{t} \mathrm{ha}^{-1}$, respectively, for fresh and dry matter).
These changes can be explained by changes in the occurrence of the rainy and cultivation season, by delaying and shortening (El Niño) and by anticipating and increasing (La Niña) the total cycle, as observed by Carvalho et al. (2013).

\section{CONCLUSIONS}

The DSSAT/CANEGRO model showed satisfactory performance in simulations of growth variables (fresh and dry matter production, tillers, LAI and plant height) of sugarcane variety RB93509 in plant and ratoon crop for the region of Rio Largo, Alagoas. Furthermore, the model had good performance in simulations of some water balance components as evaporation, transpiration and crop evapotranspiration. Thus, these results allow us to use the DSSAT model to develop climate and management scenarios to better understand sugarcane agrosystem and relate it to other studies involving, for example, the effects of climate change on their potential yield. So, we concluded that DSSAT model has great potential to simulate sugarcane growth variables and its use should be expanded to other locations in the Zona da Mata region of Brazil.

It was concluded that the best planting time for sugarcane in the region of Rio Largo-AL was on October 30. However, this condition can be influenced by the occurrence of El Niño and La Niña events of strong intensity, modifying the normal patterns of the best planting time. In El Niño and La Niña years of strong intensity, the best planting time was on January 15 and September 30, respectively.

\section{ACKNOWLEDGMENTS}

The authors thank the Coordination of Improvement of Higher Level Personnel (CAPES) for granting postdoctoral scholarship to the first author.

\section{Authors' contributions}

Alexsandro Claudio dos Santos Almeida and Iedo Teodoro carried out the agricultural experiment; André Luiz de Carvalho and José Leonaldo de Souza did the calibration and evaluation of DSSAT/CANEGRO model for 
sugarcane for the region study, as well as all simulations for different plant times. All other authors participated in the writing process of the article.

\section{REFERENCES}

Abreu, M. L., M. A. Silva, I. Teodoro, L. A. Holanda and G. D. S. Neto. 2013. Crescimento e produtividade de cana-de-açúcar em função da disponibilidade hídrica dos tabuleiros costeiros de alagoas. Bragantia. 72: 262-270.

Allen, R. G., L. S. Pereira, D. Raes and M. Smith. 1998. Crop Evapotranspiration-Guidelines for Computing Crop water Requirements. Roma: FAO. Irrigation and Drainage Paper. No. 56.

Almeida, A. C. S., J. L. Souza, I. Teodoro, G. V. S. Barbosa, G. M. Filho and R. A. Jr. Ferreira. 2008. Desenvolvimento vegetativo e produção de variedades de cana-de-açúcar em relação à disponibilidade hídrica e unidades térmicas. Ciência Agrotecnol. 32: 1441-1448.

Bezuidenhout, C. N., G. J. O'leary, A. Singels and V. B. Bajic. 2003. A process based-based model to simulate changes in tiller density and light interception of sugarcane crops. Agric. Syst. 76: 589-599.

Boutraa, T., A. Akhkha, A. A., Al-Shoaibi and A. M. Alhejeli. 2010. Effect of water stress on growth and water use efficiency (WUE) of some wheat cultivars (Triticum durum) grown in Saudi Arabia. J. Taibah Univ. Sci. 3: 39-48.

Carvalho, A. L., R. S. C. Menezes, R. S. Nóbrega, A. S. Pinto, J. P. H. B. Ometto, C. V. Randow and A. Giarolla. 2015. Impact of climate changes on potential sugarcane yield in Pernambuco, northeastern region of Brazil. Renew. Energy. 78: 26-34.

Carvalho, A. L., J. L. Souza, G. B. Lyra and E. C. Silva. 2013. Estação chuvosa e de cultivo para a região de Rio Largo, alagoas baseada em métodos diretos e sua relação com o El niñooscilação sul. Rev. Bras. Meteorol. 28: 192-198.

Ferreira, R. A. Jr., J. L. Souza, J. F. Escobedo, I. Teodoro, G. B. Lyra and R. A. A. Neto. 2014. Cana-de-açúcar com irrigação por gotejamento em dois espaçamentos entrelinhas de plantio. Rev. Bras. Eng. Agríc. Ambient. 18: 798-804.

Fietz, C. R., C. J. Silva, E. Comunello, D. L. Flumignan and J. R. A. L. Filho. 2015. Época Preferencial Para Plantio da Cana-de-açúcar de ano e meio, com base no Risco Climático, na Região sul de mato Grosso do Sul. Embrapa Agropecuária Oeste. (Circular Técnica), Dourados.

Jones, J. W., G. Hoogenboom, C. H. Porter, K. J. Boote, W. D. Batchelor, L. A. Hunt, P. W. Wilkens, U. Singh, A. J. Gijsman and J. T. Ritchie. 2003. The DSSAT cropping system model. Eur. J. Agron. 18: 235-265.

Jones, M. R., A. Singels and A. C. Ruane. 2015. Simulated impacts of climate change on water use and yield of irrigated sugarcane in South Africa. Agric. Syst. 139: 260-270.

Knox, J. W., J. A. R. Díaz, D. J. Nixon, M. A. Mkhwanazi. 2010. Preliminary assessment of climate change impacts on sugarcane in Swaziland. Agric. Syst. 103: 63-72.

Marin, F. R. and J. W. Jones. 2014. Process-based simple model for simulating sugarcane growth and production. Sci. Agric. 71: 1-16.

Marin, F. R., J. W. Jones, F. Royce, C. Suguitani, J. L. Donzeli, W. J. P. Filho and D. S. P. Nassif. 2011. Parameterization and evaluation of predictions of DSSAT/CANEGRO for Brazilian sugarcane. Agron. J. 103: 304-315.

Marin, F. R., J. W. Jones, A. Singels, F. Royce, E. D. Assad, G. Q. Pellegrino and F. J. Barbosa. 2012. Climate change impacts on sugarcane attainable yield in Southern Brazil. Clim. Change. 117: 227-239.

Meneses, T. N. and R. S. Resende. 2016. Influência de épocas de plantio na eficiência do uso da água da chuva em cultivo irrigado de cana-de-açúcar. Irriga. 1: 291-305.

Nassif, D. S. P., F. R. Marin, W. J. P. Filho, R. S. Resende and G. Q. Pellegrino. 2012. Parametrização e avaliação do modelo DSSAT/canegro para variedades brasileiras de cana-de-açúcar. Pesqui. Agropecu. Bras. 47: 311-318.

Ritchie, J. T. 1998. Soil water balance and plant water stress In: Tsuji, G. Y., G. Hoogenboom and P. K. Thornton (Eds.), Understanding Options for Agricultural Production. Kluwer, Dordrecht, p. 41-53.

Silva, R. F. 2012. Calibração do modelo DSSAT/CANEGRO Para a Cana-de-açúcar e Seu uso Para a Avaliação do Impacto das Mudanças Climáticas. Viçosa, Dissertação (Mestrado em Meteorologia Agrícola)-Universidade Federal de Viçosa, p. 67.

Singels, A. and C. N. Bezuidenhout. 2002. A new method of simulating dry matter partitioning in the Canegro sugarcane model. Field Crops Res. 78: 151-164.

Singels, A., M. Jones and M. Van der Berg. 2008. DSSAT v.4.5 DSSAT/ CANEGRO: Sugarcane Plant Module: Scientific Documentation. International Consortium for Sugarcane Modeling: South African Sugarcane Research Institute, Mount Edgecombe, p. 34.

Singels, A., M. Van der Berg, M. A. Smit, M. R. Jones and R. Van Antwerpen. 2010. Modelling water uptake, growth and sucrose accumulation of sugarcane subjected to water stress. Field Crops Res. 117: 59-69.

Souza, J. L., G. M. Filho, R. F. F. Lyra, I. Teodoro, E. A. Santos, J. L. Silva, P. R. T. Silva, A. H. Cardim and E. C. Amorin. 2004. Análise da precipitação pluvial e temperatura do ar na região do tabuleiro costeiro de maceió, AL. Período 1972-2001. Rev. Bras. Agrometeorol. 12: 131-141.

Teodoro, I., J. D. Neto, L. A. Holanda, G. D. S. Neto, J. L. Souza, G. V. S. Barbosa and G. B. Lyra. 2015. Weather variables, water balance, growth, and agro industrial yield of sugarcane. Engenharia Agríc (Online). 35: 76-88.

Thorp, K. R., K. C. Dejonge, A. L. Kaleita, W. D. Batchelor and J. O. Paz. 2008. Methodology for the use of DSSAT models for precision agriculture decision support. Comput. Electron. Agric. 64: 276-285.

Van Antwerpen, R. 1998. Modelling Root Growth and Water Uptake of Sugarcane Cultivar NCo 376. Ph.D. Thesis, University of the Orange Free State, Bloemfontein. 